\title{
Analysis of the Ecological Characteristics of Piperaceae in Tangkahan Forest, Langkat Regency, North Sumatra Province
}

\author{
Dyan Rahmaito Siregar ${ }^{1}$, T. Alief Aththorick ${ }^{2}$, Etti Sartina Siregar ${ }^{3}$ \\ ${ }^{1,2,3}$ Department of Biology, Faculty Mathematics and Natural Sciences, Universitas Sumatera Utara. Jl. \\ Bioteknologi No. 1, Medan, 20155, North Sumatra, Indonesia. \\ Corresponding Author: Dyan Rahmaito Siregar
}

DOI: https://doi.org/10.52403/ijrr.20220160

\begin{abstract}
Tangkahan is a tourist area that has a stretch of tropical rain forest with lowlands. In addition, the Tangkahan area also has a very wide area and a lot of biodiversity such as flora and fauna. The purpose of this study is to analyze the ecological characteristics of piperaceae in Tangkahan Forest, Langkat Regency, North Sumatra Province. This type of research is descriptive research. This research technique is an observation technique. Data retrieval using secondary data. The results of the research in the Tangkahan Forest area were found as many as 16 types of Piperaceae along with their ecological information.
\end{abstract}

Keywords: Ecological, Characteristics,

Piperaceae

\section{INTRODUCTION}

Indonesia has a diversity of plants in highland areas such as on hillsides or forests. One example of plant diversity in highland areas or in the hills of Tangkahan forest is various types of Piperaceae. Piperaceae theoretically consists of 13 genera and is estimated to be $\pm 2,658$ species. This plant has a very wide distribution area, in tropical and subtropical areas ranging from lowlands to highlands. A good natural habitat for Piperaceae is in a moist, humus-rich place (Purnomo, 2000; Tjitrosoepomo, 1994). Piperaceae is one of the families in the order Piperales that has the characteristics of habitus partly berbatang or tree-shaped, some scattered and shrubs or perdu, aromatic leaves, compound flowers arranged in strands, small fruit, dry, and hard.

Tangkahan is a tourist area that has a stretch of tropical rain forest with lowlands. In addition, the Tangkahan area also has a very wide area and a lot of biodiversity such as flora and fauna. The community has developed the Tangkahan Area as a natural tourist area by making elephants as one of the objects of tourist attraction (Irni et al., 2016).

Forest areas are ecotourism, because forests are unique in terms of natural scenery and rich biodiversity that can be used as an attraction for an area. In this case, tourism is an activity that is inseparable from conservation activities. Natural tourism activities which are currently experiencing an increase in tourist activities include relaxing walks in the wild, hiking or camping activities, overall these activities are carried out to enjoy natural beauty and tourist attractions in ecotourism development areas using the concept of conservation and environmental preservation (Maharani, 2016).

Indonesia as a country that has abundant natural resources and has a lot of potential that can be managed into an ecotourism. The large number of tourism potentials that have triggered the rapid development of ecotourism in Indonesia, for 
example ecotourism areas in Indonesia such as the Tangkahan Ecotourism Area, North Sumatra Province. The Tangkahan area is an ecotourism activity managed by local communities and has been around for a long time. Currently the Tangkahan Ecotourism Area has become a leading tourism destination in North Sumatra. This ecotourism area, which opened in 2001 and was inaugurated in February 2004, is an example of an ecotourism area with local community participation in nature conservation (Yusnikusumah and Sulystiawati, 2016).

The Piperaceae family which is used as medicine and an inseparable part of various cultures of people in Asia, including Indonesia. Local people in Asia including Indonesia have a habit of chewing betel leaves/flowers called betel nut. Betel nut uses various ingredients that vary from one region to another, but most of the components consist of PB leaves or flowers, gum or gambir leaves (Uncaria gambir), areca nut (Areca catechu), tobacco leaves (Nicotiana tabacum) and quicklime (calcium hydroxide) (Silalahi, 2014).

Ecological and potential studies of the Piperaceae species is a study that analyzes various aspects related to species diversity, habitat, and potential. This study is expected to reveal the diversity of Piperaceae species and their potential as medicinal ingredients, cosmetic ingredients, refreshments, ornamental plants and others.

Research on Piperaceae has been carried out in several forest areas of North Sumatra Province, including the Alam Deleng Lancuk Park, Karo Regency, North Sumatra Province by Ahdatika (2008) there are 10 species from the Piperaceae family; Aek Nauli Forest, Simalungun Regency by Rahmayani (2011) there are 10 types of the Piperaceae family; Taman Eden Forest 100 North Sionggang Village, Lumbanjulu District Anonim (2018) there are 6 types of the Piperaceae family.

Piperaceae in the Tangkahan Forest Area of North Sumatra Province based on secondary data from the local community is predicted to be approximately 21 species. Many Piperaceae species are found in the Tangkahan Forest area, but there is still no information about Piperaceae in the Tangkahan forest area. Based on the above background, the purpose of this study is to analyze the ecological characteristics of piperaceae in Tangkahan Forest, Langkat Regency, North Sumatra Province.

\section{RESEARCH METHODS}

The research method is a scientific way to obtain data with the aim of being able to describe, prove, develop and discover knowledge, theories, to understand, solve, and anticipate problems in human life (Octiva et al., 2018). The benefit of the research methods by Octiva et al. (2021) is that researchers can facilitate their work in order to arrive at the decision-making stage or conclusions. The conclusions drawn by researchers can be trusted. The conclusions drawn can be used to solve problems.

This type of research is descriptive research. Descriptive research is a type of research that aims to make a systematic, factual and accurate description of the facts and characteristics of the population of a particular area (Pandiangan et al., 2021). The purpose of this descriptive research is to make a systematic, factual and accurate description, picture, or painting of the facts, characteristics and relationships between the phenomena being investigated (Pandiangan, 2015).

This research technique is an observation technique. The observation technique is the systematic observation and recording of the phenomena being investigated (Tobing et al., 2018). The purpose of the observation technique is to get a conclusion about the object being observed. Observation also aims to describe an object and everything related to the object under study (Pandiangan, 2018).

Data retrieval using secondary data. Secondary data is data that has been processed first and only obtained by researchers from other sources as additional information (Pandiangan et al., 2018). 
Secondary data was obtained by studying literature from various literatures and by observing forest area managers.

\section{RESULT}

\section{Description of Piperaceae}

Piperaceae are mostly terna, sometimes woody plants often climb using attachment roots (Tjitrosoepomo, 2009). The position of the leaves opposite and facing, single, flat edges, bony leaves crossed (curved). Flowers are arranged in compound flowers called pepper flowers (amentum), each small without flower decoration, single or effeminate with 1-10 stamens; Pistil consists of 1-6 pieces (mostly 3 ), the head of the bear 1 with 1 will be the seeds that are upright basically. The morphological characters of Piperaceae can be seen in Figure 1 below:

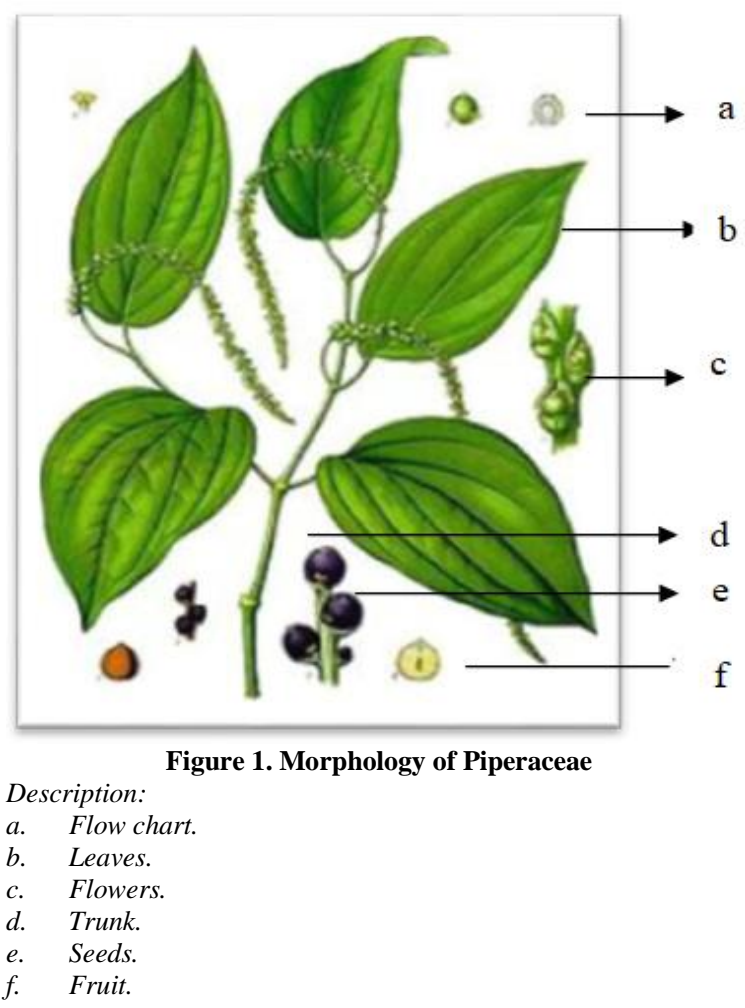

\section{Ecological Characteristics in Tangkahan Forest, Langkat Regency, North Sumatra Province}

The results of the research in the Tangkahan Forest area were found as many as 16 types of Piperaceae along with their ecological information.

\section{Peperomia laevifolia (Blume) Miq.}

Wild plants; Terrestrial habitat;

Herbs; Smooth and slippery surface; the color of the upper surface of the leaves is light green and the lower surface of the leaves is whitish green; small leaves measuring $3.5 \mathrm{~cm}$ long, $2.3 \mathrm{~cm}$ wide; curved leaves; the base of the stem; flat edge; pointed tip; hairless stalk; distinctive aroma; not blooming. Ecology: Found in areas with sufficient light intensity; live at an altitude of 0-2000 $\mathrm{m}$ above sea level.

\section{Peperomia pellucida Kunth}

Wild plants; Terrestrial habitat; Herbs; Smooth surface; the color of the upper surface of the leaves is light green and the lower surface of the leaves is light green; small leaves measuring $4.4 \mathrm{~cm}$ long and $2.2 \mathrm{~cm}$ wide; curved leaves; the base of the stem; flat edge; pointed tip; hairless stalk; distinctive aroma; not blooming. Ecology: Found in areas with sufficient light intensity; live at an altitude of $0-2000 \mathrm{~m}$ above sea level.

\section{Piper aduncum $\mathbf{L}$.}

Wild plants; Terrestrial habitat; shrubs; Smooth surface; the color of the upper surface of the leaves is light green and the lower surface of the leaves is light green; large leaves with a length of $15.5 \mathrm{~cm}$ wide $7.3 \mathrm{~cm}$; curved leaves; leaf base rounded; flat edge; pointed tip; hairy stalk; distinctive aroma; not blooming. Ecology: Found in areas with sufficient light intensity; live at an altitude of 0-2000 m above sea level.

\section{Piper baccatum Blume}

Cultivated plants; Terrestrial habitat; Liana; Smooth surface; the color of the upper surface of the leaves is light green and the lower surface of the leaves is light green; large leaves with a length of $5.5 \mathrm{~cm}$ wide $2.9 \mathrm{~cm}$; curved leaves; leaf base notched; flat edge; pointed tip; hairless stalk; distinctive aroma; not blooming. Ecology: Found in areas with sufficient light 
intensity; live at an altitude of $0-2000 \mathrm{~m}$ above sea level.

\section{Piper betle $\mathbf{L}$.}

Cultivated plants; Terrestrial habitat; Liana; Smooth surface; the color of the upper surface of the leaves is light green and the lower surface of the leaves is light green; small leaves measuring $4.4 \mathrm{~cm}$ long and $3.3 \mathrm{~cm}$ wide; curved leaves; leaf base notched; flat edge; pointed tip; hairless stalk; distinctive aroma; not blooming. Ecology: Found in areas with sufficient light intensity; live at an altitude of $0-2000 \mathrm{~m}$ above sea level.

\section{Piper caninum Blume}

Cultivated plants; Terrestrial habitat; Liana; Smooth surface; the color of the upper surface of the leaves is light green and the lower surface of the leaves is light green; large leaves with a length of $6.4 \mathrm{~cm}$ wide $5.5 \mathrm{~cm}$; curved leaves; leaf base notched; flat edge; pointed tip; hairless stalk; distinctive aroma; not blooming. Ecology: Found in areas with sufficient light intensity; live at an altitude of 0-2000 m above sea level.

\section{Piper clypeatum Wall.}

Wild plants; Terrestrial habitat; Liana; Smooth surface; the color of the upper surface of the leaves is light green and the lower surface of the leaves is light green; large leaves measuring $12 \mathrm{~cm}$ long and $8 \mathrm{~cm}$ wide; curved leaves; leaf base notched; flat edge; rounded ends; hairless stalk; distinctive aroma; not blooming. Ecology: Found in areas with sufficient light intensity; live at an altitude of $0-2000 \mathrm{~m}$ above sea level.

\section{Piper flavomarginatum Blume}

Cultivated plants; Terrestrial habitat; Liana; Smooth surface; the color of the upper surface of the leaves is light green and the lower surface of the leaves is light green; large leaves with a length of $12.8 \mathrm{~cm}$ wide $7.6 \mathrm{~cm}$; curved leaves; leaf base rounded; flat edge; pointed tip; hairless stalk; distinctive aroma; not blooming. Ecology: Found in areas with sufficient light intensity; live at an altitude of $0-2000 \mathrm{~m}$ above sea level.

\section{Piperlong Blume}

Wild plants; Terrestrial habitat; Liana; Smooth surface; the color of the upper surface of the leaves is light green and the lower surface of the leaves is light green; large leaves with a length of $9.5 \mathrm{~cm}$ wide $3 \mathrm{~cm}$; curved leaves; the base of the rhizome; flat edge; pointed tip; hairless stalk; distinctive aroma; not blooming. Ecology: Found in areas with sufficient light intensity; live at an altitude of $0-2000 \mathrm{~m}$ above sea level.

\section{Piper macrophyllum Sw.}

Wild plants; Terrestrial habitat; Liana; Smooth surface; the color of the upper surface of the leaves is light green and the lower surface of the leaves is light green; large leaves with a length of $15.2 \mathrm{~cm}$ and a width of $10.4 \mathrm{~cm}$; curved leaves; leaf base notched; flat edge; pointed tip; hairless stalk; distinctive aroma; not blooming. Ecology: Found in areas with sufficient light intensity; live at an altitude of 0-2000 m above sea level.

\section{Piper miniatum Blume}

Wild plants; Terrestrial habitat; Herbs; Smooth surface; the color of the upper surface of the leaves is light green and the lower surface of the leaves is light green; large leaves with a length of $8.5 \mathrm{~cm}$ wide $4.5 \mathrm{~cm}$; curved leaves; leaf base notched; flat edge; pointed tip; hairless stalk; distinctive aroma; not blooming. Ecology: Found in areas with sufficient light intensity; live at an altitude of 0-2000 m above sea level.

\section{Piper muricatum Blume}

Wild plants; Terrestrial habitat; Liana; Smooth surface; the color of the upper surface of the leaves is light green and the lower surface of the leaves is light green; large leaves with a length of $23 \mathrm{~cm}$ 
and a width of $15.2 \mathrm{~cm}$; curved leaves; leaf base notched; flat edge; pointed tip; hairless stalk; distinctive aroma; flower-shaped; Flower length $5.6 \mathrm{~cm}$. Ecology: Found in areas with sufficient light intensity; live at an altitude of 0-2000 $\mathrm{m}$ above sea level.

\section{Piper pedicellatum C. DC.}

Wild plants; Terrestrial habitat; Herbs; Smooth surface; the color of the upper surface of the leaves is light green and the lower surface of the leaves is light green; large leaves with a length of $9.5 \mathrm{~cm}$ wide $4.4 \mathrm{~cm}$; curved leaves; leaf base notched; flat edge; pointed tip; hairless stalk; distinctive aroma; flower-shaped; Flower length $5.6 \mathrm{~cm}$. Ecology: Found in areas with sufficient light intensity; live at an altitude of 0-2000 $\mathrm{m}$ above sea level.

\section{Piper porphyrophyllumN.E.Br.}

Cultivated plants; Terrestrial habitat; Liana; Smooth surface; the color of the upper surface of the leaves is light green and the lower surface of the leaves is light green; large leaves measuring $14.5 \mathrm{~cm}$ long and $7.9 \mathrm{~cm}$ wide; curved leaves; leaf base notched; flat edge; pointed tip; hairless stalk; distinctive aroma; not blooming. Ecology: Found in areas with sufficient light intensity; live at an altitude of $0-2000 \mathrm{~m}$ above sea level.

\section{Piper sintenense Hatus}

Wild plants; Terrestrial habitat; Liana; Smooth surface; the color of the upper surface of the leaves is light green and the lower surface of the leaves is light green; large leaves with a length of $7.5 \mathrm{~cm}$ wide $4.2 \mathrm{~cm}$; curved leaves; leaf base notched; flat edge; pointed tip; hairless stalk; distinctive aroma; not blooming.

Ecology: Found in areas with sufficient light intensity; live at an altitude of 0-2000 $\mathrm{m}$ above sea level.

\section{Piper stylosum Miq.}

Wild plants; Terrestrial habitat; Herbs; Smooth surface; the color of the upper surface of the leaves is light green and the lower surface of the leaves is light green; large leaves with a length of $15 \mathrm{~cm}$ wide $7.8 \mathrm{~cm}$; curved leaves; the base of the stem; flat edge; pointed tip; hairy stalk; distinctive aroma; not blooming.

Ecology: Found in areas with sufficient light intensity; live at an altitude of 0-2000 $\mathrm{m}$ above sea level.

\section{CONCLUSION}

The results of the research in the Tangkahan Forest area were found as many as 16 types of Piperaceae along with their ecological information.

\section{Acknowledgement: None}

\section{Conflict of Interest: None}

\section{Source of Funding: None}

\section{REFERENCES}

1. Ahdatika L. (2008). Keanekaragaman Piperaceae dan Rubiaceae di Taman Wisata Alam Deleng Lancuk Kabupaten Karo Sumatera Utara. Tesis. Program Pascasarjana Universitas Sumatera Utara.

2. Anonim. (2018). Inventarisasi Piperaceae di Kawasan Hutan Taman Eden 100 Desa Sionggang Utara Kecamatan Lumbanjulu Kabupaten Toba Samosir Sumatera Utara. Medan: Universitas Sumatera Utara, Departemen Biologi. http://edsams.blogspot.com/2018/08/contoh-jurnalinventarisasipiperaceae.html.

3. Irni J, Masy'ud B, \& Haneda NF. (2016). Keanekaragaman Jenis Kupu-kupu Berdasarkan Tipe Tutupan Lahan dan waktu Aktifnya di Kawasan Penyangga Tangkahan Taman Nasional Gunung Leuser. Jurnal Media Konservasi, 21(3), 225-232.

4. Maharani I. (2016). Analisis Kelayakan Potensi Ekowisata pada Kawasan Wisata Alam Bungi Kecamatan Kokalukuna Kota Baubau. Skripsi. Kendari: Universitas Halu Oleo, Fakultas Kehutanan dan Ilmu Lingkungan.

5. Octiva, C. S., Irvan, Sarah, M., Trisakti, B., \& Daimon, H. (2018). Production of Biogas from Co-digestion of Empty Fruit Bunches (EFB) with Palm Oil Mill Effluent (POME): Effect of Mixing Ratio. Rasayan J. Chem., 11(2), 791-797. 
6. Octiva, Cut Susan, Indriyani, \& Santoso, Ari Beni. (2021). Effect of Stirring Codigestion of Palm Oil and Fruith for Biogas Production to Increase Economy Benefit. Budapest International Research and Critics Institute-Journal, 4(4), 14152-14160. DOI: https://doi.org/10.33258/birci.v4i4.3521.

7. Pandiangan, Saut Maruli Tua. (2015). Analisis Lama Mencari Kerja Bagi Tenaga Kerja Terdidik di Kota Medan. Skripsi. Medan: Fakultas Ekonomi dan Bisnis, Program Studi Ekonomi Pembangunan, Universitas Sumatera Utara. https://www.academia.edu/52494724/Analis is_Lama_Mencari_Kerja_Bagi_Tenaga_Ker ja_Terdidik_di_Kota_Medan.

8. Pandiangan, Saut Maruli Tua. (2018). Analisis Faktor-faktor yang Mempengaruhi Penawaran Tenaga Kerja Lanjut Usia di Kota Medan. Tesis. Medan: Fakultas Ekonomi dan Bisnis, Program Studi Ilmu Ekonomi, Universitas Sumatera Utara. http://repositori.usu.ac.id/bitstream/handle/1 23456789/10033/167018013.pdf?sequence= $1 \&$ isAllowed $=\mathrm{y}$.

9. Pandiangan, Saut Maruli Tua, Rujiman, Rahmanta, Tanjung, Indra I., Darus, Muhammad Dhio, \& Ismawan, Agus. (2018). An Analysis on the Factors which Influence Offering the Elderly as Workers in Medan. IOSR Journal of Humanities and Social Science (IOSR-JHSS), 23(10), 76-79. DOI: 10.9790/0837-2310087679. http://www.iosrjournals.org/iosrjhss/papers/Vol.\%2023\%20Issue10/Version -8/K2310087679.pdf.

10. Pandiangan, Saut Maruli Tua, Resmawa, Ira Ningrum, Simanjuntak, Owen De Pinto, Sitompul, Pretty Naomi, \& Jefri, Riny. (2021). Effect of E-Satisfaction on Repurchase Intention in Shopee User Students. Budapest International Research and Critics Institute-Journal, 4(4), 77857791. DOI: https://doi.org/10.33258/birci.v4i4.2697.
11. Purnomo S. (2000). Species Anggota Suku Piperaceae di Lereng Selatan Gunung Merapi. Fakultas Biolog Universitas Gadjah Mada.

12. Rahmayani. (2011). Keanekaragaman Piperaceae dan Rubiaceae di Hutan Aek Nauli Kabupaten Simalungun Sumatera Utara. Tesis. Medan: Universitas Sumatera Utara, Program Pascasarjana.

13. Silalahi, M. (2014). The Ethnomedicine of the Medicinal Plants in Subethnic Batak, North Sumatra and the Conservation Perspective. Dissertation. Indonesia: Universitas Indonesia.

14. Tobing, Murniati, Afifuddin, Sya'ad, Rahmanta, Huber, Sandra Rouli, Pandiangan, Saut Maruli Tua, \& Muda, Iskandar. (2018). An Analysis on the Factors Which Influence the Earnings of Micro and Small Business: Case at Blacksmith Metal Industry. Academic Journal of Economic Studies, 5(1), 17-23. https://www.ceeol.com/search/articledetail id $=754945$.

15. Tjitrosoepomo G. (1994). Morfologi Tumbuhan. Yogyakarta: Universitas Gadjah Mada.

16. Tjitrosoepomo G. (2009). Morfologi Tumbuhan. Yogyakarta: Universitas Gadjah Mada.

17. Yusnikusumah TR, \& Sulystiawati E. (2016). Evaluasi Pengelolaan Ekowisata di Kawasan Ekowisata Tangkahan Taman Nasional Gunung Leuser Sumatera Utara. Jurnal Perencanaan Wilayah dan Kota, 27 (3), 173-189.

How to cite this article: Dyan Rahmaito Siregar, T. Alief Aththorick, Etti Sartina Siregar. Analysis of the ecological characteristics of piperaceae in Tangkahan Forest, Langkat Regency, North Sumatra Province. International Journal of Research and Review. 2022; 9(1): 522-527. DOI: https://doi.org/10.52403/ijrr. 20220160 